\title{
Effect of early-to-mid gestational maternal nutrient restriction followed by adolescent-onset obesity on the gene expression of inflammatory markers in pericardial adipose tissue
}

\author{
N. Patel ${ }^{1}$, S. Sebert ${ }^{1}$, D. S. Gardner ${ }^{1}$, R. Bell ${ }^{2}$, H. Budge $^{1}$ and M. E. Symonds ${ }^{1}$ \\ ${ }^{1}$ Centre for Reproduction and Early Life, Institute of Clinical Sciences, University of Nottingham, UK and \\ ${ }^{2}$ Alberta Institute of Human Nutrition, University of Alberta, Edmonton, Canada
}

Maternal nutrient restriction targeted during early fetal adipose tissue development can result in an enhanced inflammatory response within perirenal adipose tissue following adolescent-onset obesity despite no difference in fat mass compared with obese controls ${ }^{(1)}$. The extent to which comparable adaptations may occur within the fat surrounding the heart (i.e. pericardial) is not known and was therefore the aim of the present study.

Pregnant sheep ( $n$ 20) were randomly assigned to a normal $(7 \mathrm{MJ} / \mathrm{d}$ ) or nutrient-restricted diet (NRO; $3.5 \mathrm{MJ} / \mathrm{d}$ ) from day 30 to day 80 of gestation (term $147 \mathrm{~d}$ ) and fed to requirements thereafter. After birth the offspring from all the groups were kept with their mothers for the lactation period of 10 weeks. Mothers were fed to requirement for lactation purposes. To promote obesity the control (O) and NRO groups between the 4th and 12th months after birth were subjected to increased energy availability of concentrated pellets ad libitum and confined into a space of seventeen animals per $50 \mathrm{~m}^{2}$ to restrict physical activity (stocking environment). Once the sheep reached 1 year of age they were humanely killed. The pericardial tissue was immediately frozen in liquid $\mathrm{N}_{2}$ and total RNA was extracted followed by realtime PCR analysis. Analysis of results was calculated using the $2^{-\Delta \mathrm{CT}}$ method with $18 \mathrm{~s}$ used as a housekeeping gene.

Pericardial fat mass (g) was lower in the NRO group compared with controls (O 328 (SE 39), NRO 232 (SE 39); $P<0.05$ ). Gene expression of adiponectin, insulin receptor, TNF $\alpha$, IL-18, glucose-regulated $78 \mathrm{kDa}$ protein and GLUT4 were not different between groups. The mRNA abundance for both IL- 6 and monocyte chemoattractant protein-1 were, however, both up regulated in the NRO group (fold change; O 0.075 (SE 0.01), NRO 2.0 (SE 1.0) and O 1.1 (SE 0.2), NRO 2.2 (SE 0.6) respectively; $P<0.05$ ).

Despite the NRO group possessing less pericardial adipose tissue, there was a pronounced up-regulation in gene expression of key inflammatory markers in this fat depot. The extent to which this up-regulation may contribute to the altered metabolic profile in the hearts of these offspring ${ }^{(2)}$ is currently under investigation.

1. Sharkey D, Fainberg HP, Wilson V et al. (2008) FASEB Journal (Epublication ahead of print version; doi:10.1096/fj.08-114330).

2. Chan LLY, Sebert SP, Hyatt MA et al. (2009) Am J Physiol Regul Integr Comp Physiol (Epublication ahead of print version; doi:10.1152/ ajpregu.91019.2008). 